\title{
KIMBERLITE ERUPTION PROCESSES
}

\author{
E.M.W. Skinner ${ }^{1}$ and J.S. Marsh ${ }^{1}$ \\ ${ }^{1}$ Rhodes University, South Africa
}

\section{INTRODUCTION}

There is a continuing debate concerning the processes involved in the explosive eruption of kimberlites. One school believes that magmatic processes involving juvenile volatile components and decompression- +/- crystallization- induced exsolution (first and second boiling) are mainly responsible (e.g. Clement and Reid, 1989), whereas another school believes that fuel-coolant interaction between meteoric waters and hot kimberlite magma (phreatomagmatism) is the only process possible (e.g. Lorenz, 2000). In this contribution we present a model for the eruption of classical kimberlite pipes mainly by magmatic processes although we recognize that in some cases phreatomagmatism may play a limited role. This model is based on a number of critical petrographic features. These include the recognition of in situ transitional-facies kimberlites present in all cases at the contact between hypabyssal- and diatreme-facies kimberlite and the identification of distinctly different kimberlite rock types present in the crater zones of different pipe types. These pipe types correspond to the three distinct styles of pipe emplacement recognized by Field and Scott Smith (1999). In this study the different pipe styles are referred to as pipe-classes 1 to 3 .

\section{THE THREE PIPE CLASSES}

Class 1 is the classical pipe that more or less obeys the Hawthorne (1975) model. Only Class 1 pipes have diatreme-zones filled by typical diatreme-facies kimberlite as described by Clement and Skinner (1985). Also present in classical Class 1 pipes, are distinct zones (tens of meters wide) of kimberlite, transitional between diatreme- and hypabyssal-facies that occur at the interface between the two facies. The nature of these transitional-facies kimberlites is remarkably similar from one Class 1 pipe to the next. Like diatreme-, transitional-facies kimberlites with characteristic segregationary textures are interpreted to form as a consequence of first and second boiling that is initiated at depths of around $2 \mathrm{~km}$ from the original surface.
Class 2 pipes, such as the Forte a la Corne pipes in Canada, typically form shallow saucer-shaped craters. In these pipes hot kimberlite magma appears to have risen to relatively shallow depths of $<500 \mathrm{~m}$ prior to eruption. Phreatomagmatism is possible particularly in crater excavation but the nature of the predominantly pyroclastic rocks in the throats of these pipes indicates that the formation of these rocks may be by some other means (Scott Smith, pers. comm.).

Class 3 pipes, such as the Jwaneng pipe in Botswana, typically form, steep-sided craters $>500 \mathrm{~m}$ deep. In these pipes the petrography of kimberlite magmaclasts enclosed in mainly resedimented volcaniclastic kimberlites indicate crystallization at depth, fragmentation on eruption to surface, and hydraulic reworking during the infilling of the craters. The main processes responsible for crater excavation are thought to be magmatic (Machin 2000) but detailed mechanisms would be unlike those operative in Class 1 pipes.

Field and Scott Smith (1999) argue that the pipe classes differ in their geographical occurrence and geological setting, with these factors having important influences on the style of emplacement. However, petrographic work carried out in this study on the crater-facies rocks from different pipe classes shows that the main reason for different emplacement styles, may be due to differences in kimberlite composition (particularly volatile composition), rather than differences in geological setting. Compositional differences are reflected in unique petrographic features. Most Class 1 crater-facies kimberlites contain magmaclasts that are small (mainly ashsized), have pelletal shapes, contain relicts of microlitic diopside, are devoid of calcite and the grain sizes of the primary finer-grained matrix minerals not replaced by microlitic diopside are similar to grain sizes in typical hypabyssal-facies kimberlites. The latter suggests that these minerals have crystallized at depth under normal hypabyssal conditions, prior to the diatremeforming process. Crater-facies kimberlites in Class 2 pipes contain magmaclasts that are commonly lapilli-sized $(>2 \mathrm{~mm})$, may be amoeboid in shape, may contain calcite and calcite-filled vesicles but are devoid of relicts of 
microlitic diopside. Here grain sizes of the finergrained primary matrix minerals may be very small and even glassy. Crater-facies kimberlites in Class 3 pipes contain magmaclasts that are typically broken, exhibit a large range in sizes (ash to lapilli-size) and may contain calcite. But they are devoid of microlitic diopside and grain sizes of the finer-grained primary matrix minerals (which may be relatively well preserved) are similar to the grain sizes of typical hypabyssal-facies kimberlites that have crystallized at depth.

Having recognized these different rock types in different pipe classes it has been possible to classify other pipes without recourse to knowledge of pipe styles or shapes by simply characterizing the rock types present in, for example, borehole cores. This work shows that more than one class can occur in a kimberlite pipe complex (e.g. some of the Archangelsk pipes in Russia). It also shows that two or all three classes may occur together in the same geological area (e.g. in the Udachnaya cluster in Siberia, Russia and kimberlites in Angola).

Differences in the $\mathrm{CO}_{2} / \mathrm{H}_{2} \mathrm{O}$ ratio of the fluid phase will influence the nature of the kimberlite solidus provided this influence is similar to that established for peridotite by Wyllie (1987). The solidus of water-rich peridotite magma has a pronounced negative PT slope, which steepens and becomes positive with increasing $\mathrm{CO}_{2} / \mathrm{H}_{2} \mathrm{O}$ in the fluid phase. Thus water-rich kimberlite magma is likely to behave differently to carbonatitic kimberlite magma as it approaches the surface. Specifically water-rich kimberlite is likely to crystallize at depth and will not flow through to the surface unless it undergoes explosive emplacement. Alternatively carbonaterich kimberlite magmas or those rendered waterpoor by phlogopite crystallization may approach the surface as hot magma.

\section{MAGMATIC VERSUS PHREATOMAGMATIC}

Based on Burnham's (1985) model it is proposed that, kimberlite melt containing dissolved juvenile volatiles (mainly water) infiltrates its way upward to within $3 \mathrm{~km}$ of the surface. Depending on the solubility and saturation of volatile components (about which little is known for kimberlite compositions), volatile pressure within the water-rich melt is likely to increase as a consequence of decompression and crystallization (Cas and Wright, 1987). The melt fraction is likely to decrease to a point where the vapour pressure of the melt is equal to or exceeds the confining pressure and exsolution to a supercritical fluid or gas occurs. $\mathrm{P} \Delta \mathrm{V}$ energy is generated as a function of the increase in volume due to the phase change from melt to gas These processes are interpreted to result in cracking in the surrounding rocks to form contact breccias at depth and at lower pressure, cracking through to surface. Once the surface is breached, sudden depressurization, exsolution, expansion and volume increase of the gas derive considerable additional energy. Explosive eruption occurs. Magmatic processes can generate enormous amounts of energy particularly if exsolution occurs within a small time frame over the entire magma column, which probably extends vertically from 1 to $2 \mathrm{~km}$. At the Kimberley Mines diatreme-facies kimberlites extend down to just below $2 \mathrm{~km}$ from the original surface (Clement, 1982). Class 1-pipe complexes are interpreted to form from only a few separate large explosive eruptions. This is indicated by the presence of only a few diatreme-facies types present in any one pipe complex and by the fact that the Class 1 craters appear to be filled by an undisturbed sequence of bedded but massive pyroclastic rocks overlain by resedimented volcaniclastic rocks.

In the case of normal phreatomagmatic systems, there is evidence for many hundreds of much smaller explosions. In these explosions, kimberlite melt must rise to above $700 \mathrm{~m}$; the depth or pressure ( $<220$ bars) at which water goes subcritical. Groundwater must be available such that the hot magma mixes with the water. If low energy shock waves pass through the magmawater premix, the vapour film that has formed around the magma can collapse quasi-coherently (Wohletz and Zimanowski, 2000). Water undergoes a phase change from liquid to gas and $\mathrm{P} \Delta \mathrm{V}$ energy is generated as a result of the volume increase. Cracking through to surface is then followed by dramatic expansion and volume increase as is the case in magmatic explosions. The amount of energy generated at each explosion is limited by the extent of the interface between water and magma. However very many explosions are likely as new magma comes into contact with new water. Compared with magmatic explosions, phreatomagmatic 
explosions are likely to be much smaller but they are considerably more numerous and the total energy generated could be similar.

If the kimberlite magma is volatile-rich, volatile exsolutions are likely to preceed any phreatomagmatic process because exsolution is likely to occur at depths where water is supercritical. However, explosions induced by magmatic processes will be diminished or possibly even avoided if water originally present in the melt is locked-up in high-temperature, early-crystallizing, water-bearing minerals like phlogopite or if crystallization is inhibited by the presence of relatively high proportions of dissolved $\mathrm{CO}_{2}$ (re. later discussion).

\section{CHARACTER OF KIMBERLITE FACIES}

The parental hypabyssal-facies kimberlites are petrographically and compositionally significantly different from their related diatreme-facies kimberlites. But until now the transition from one facies to the other has not been well understood.

\section{HYPABYSSAL-FACIES}

Most root-zone, hypabyssal-facies kimberlites occur as uniformly textured rocks, with earlier crystallizing minerals (including olivine, phlogopite, monticellite, opaque minerals and perovskite) evenly distributed within a base of later crystallizing calcite and serpentine. But, occasionally in dykes, and commonly in the root zones of pipes, hypabyssal-facies kimberlites exhibit segregationary textures which, when well-developed, form a distinctive kimberlite type known as globular-segregationary kimberlites (Clement and Skinner, 1985). Here earlier crystallizing silicates and oxides occur as segregated larger globules and smaller pellets set within an inter-globular/pelletal matrix of later crystallizing calcite and serpentine. This texture is ascribed to some form of exsolution-induced immiscibility (re. Clement, 1975 and Clement and Reid, 1989) There is no question that this segregation occurs, for whatever reason, in the hypabyssal environment.

Another feature of root zones is the so-called contact breccias that are found in wall rocks adjacent to hypabyssal-facies plugs (re. Clement, 1982). Brecciation is thought to have been caused by fracturing as a consequence of first boiling but without breakthrough to the surface and explosive eruption, because in such cases the confining pressure is interpreted as being too high to allow this to happen

\section{DIATREME-FACIES}

Fresh, relatively unaltered diatreme-facies kimberlites are remarkably similar. Textures are dominated by the presence of pelletal to globular magmaclasts, individual olivine xenocrysts, earlier "kimberlitized" xenoliths plus relatively fresh country rock xenoliths set in an interfragmental matrix of mainly serpentine. All are mineralogically dominated by ultra fine-grained diopside, which is interpreted to occur as an autometasomatic replacement mineral in the kimberlite magmaclasts and, in some cases, in the inter-fragmental matrix as well. All relatively fresh diatreme-facies kimberlites are characterized by a scarcity of primary calcite, and are compositionally $\mathrm{CO}_{2}$-poor relative to other kimberlite facies.

\section{TRANSITIONAL-FACIES}

Since the 7IKC, more detailed data has become available on several Class 1 kimberlites pipes in southern Africa, West Africa and the Hearn pipe in Canada. These kimberlites reveal the presence of distinct zones of what is referred to here as transitional-facies kimberlites. In most cases these kimberlites occur at the interface between root- (hypabyssal) and diatreme-zones. They exhibit a continuing series of mineralogical and textural features that range from being similar to hypabyssal to being similar to diatreme rock, depending upon location in the transition zone. For example specimens that are similar to hypabyssal kimberlites may have small "pods" of microlitic diopside in a host of normal, uniformly textured hypabyssal-facies kimberlite whereas specimens similar to diatreme kimberlites may have pelletal textures and abundant microlitic diopside with irregularshaped "pods" (not magmaclasts) of almost normal hypabyssal-facies kimberlite. Besides the appearance of abundant microlitic diopside and appearance of pelletal textures, other changes cross the transition zone towards diatreme-facies occur. These include; the disappearance of calcite, the appearance of abundant microlitic serpentine, the disappearance of fresh olivine, 
the disappearance of hypabyssal-facies textures except where present in large globular segregations and the appearance of relatively fresh country rock xenoliths.

\section{DISCUSSION}

The first changes that occur are interpreted to involve the disappearance or dissociation of calcite and the alteration of olivine to serpentine to generate sufficient $\mathrm{CaO}$ and additional $\mathrm{SiO}_{2}$ to allow for the crystallization of abundant diopside. At the same time earlier crystallized, silicate-dominant pellets and/or globules segregate in a matrix of mainly volatile constituents. The driving processes for diopside generation and pelletal segregation are thought to be first and second boiling. As discussed earlier most of these changes are thought to occur within the hypabyssal environment prior to explosive eruption. Diatreme-facies kimberlite form upon explosive eruption when relatively fresh country rock inclusions are added.

Deep mining to depths of over $1 \mathrm{~km}$ of southern African kimberlites, some of which have been eroded by as much as $1,4 \mathrm{~km}$ (Hawthorne, 1975) shows that the transition from root-zones to diatreme-zones is initiated at depths of around $2 \mathrm{~km}$ from the original surface. At this depth lithostatic pressure is in the order of 600bars. The unaltered nature of enclosed xenolithic material including wood fragments and the crystallization of low temperature serpentine suggests that the temperature of the newly formed diatreme-facies kimberlite undergoes a dramatic and rapid drop in temperature from around $1200^{\circ} \mathrm{C}$ to $\angle 250^{\circ} \mathrm{C}$. It is likely that this drop in temperature is caused essentially by the dramatic expansion of gasses, which occur during eruption.

In rare cases transitional-facies kimberlite may occur together with hypabyssal-facies kimberlite but without the association of diatreme-facies kimberlite (e.g. the Dark Piebald kimberlite at the Premier Mine, where over $>1 \mathrm{~km}$ of vertical section is exposed by mining and drilling). Here it is assumed that the second boiling process was aborted prior to explosive eruption. At Premier Mine, the Black kimberlite occurs as hypabyssaltransitional- and diatreme-facies types also over the $>1 \mathrm{~km}$ vertical section. Here the change from root-zone to diatreme-zone is clearly not horizontal as suggested by the Hawthorne (1975) model, but rather occurs in an inclined sense through a substantial section of the original magma chamber.

\section{PROPOSED ERUPTION MECHANISM FOR CLASS I PIPES}

It is envisaged that within a Class 1-pipe complex, in individual pipe forming events, second boiling generates one large explosion that is initiated from around $1 \mathrm{~km}$ below the original surface and is instantaneously propagated downwards through the magma column to depths of around $2 \mathrm{~km}$. The three-dimensional shape of the diatreme-zone, an inverted cone with a slope angle of approximately $80^{\circ}$, is similar to the shape of deep explosive vents produced by manmade explosions (Rice, 1999). The shape is produced by a single event rather than the multiple-staged downward reworking postulated by Clement (1982). The initial large subsurface explosion is likely to generate potent shock waves, which when they rebound from the surface, should create explosive spalling of cap rock material (uncontaminated by kimberlitic components), which is likely to be blown into. oblivion. The relative scarcity of cap rock material in many pipes can thus be explained. An upward rush of expanding kimberlite gasses and solid components follows and a deep crater is produced. Within the vent accelerated mixing of the gases and mainly solidified pelletal kimberlitic components creates the ideal conditions for the generation of a fluidized system (McCallum, 1985). At initially high gas velocities kimberlite is erupted from the vent and back-fall kimberlite is deposited in a tuff-ring around and within the crater.

Convective overtuning (spouting) of the fluidized system occurs in order to produce the homogeneity seen in the diatreme-facies rocks. But downward sinking of some cap-rock fragments also occurs to produce the so-called "floating reef" deposits. The eruption process is very rapid and the elapsed time from initial explosion to final settling of the fluidized system happens in a relatively short time (in minutes rather than hours).

\section{CONCLUSION}

Three pipe classes are recognized. Only class 1 pipes contain diatreme-facies kimberlite as well 
as newly recognized transitional-facies kimberlite. This kimberlite occurs mainly at the interface between hypabyssal- and diatremefacies at depths from around $2 \mathrm{~km}$ from the original surface. The unique petrographic characteristics of the three facies are interpreted to form as a consequence of decompression and crystallization-induced exsolution of juvenile volatiles. The typical solidus conditions for most hydrous kimberlites will prevent the flow of hot magma to levels where phreatomagmatism is possible. Thus for Class 1 pipes the preferred eruption mechanism is magmatic.

From the occurrence of kimberlite lavas in some Class 2 pipes and the nature of the magmaclasts present it is obvious that relatively hot magma rose to the surface. Phreatomagmatic explosive eruption is possible during crater formation but the nature of the crater deposits suggests that magmatic processes are also likely.

Class 3 pipe craters appear to have been formed after the crystallization of earlier hypabyssalfacies kimberlite at depths of up to $1 \mathrm{~km}$. In such cases magmatic processes of some sort are thought to be responsible.

However, if magmatic processes are operative in class 2 and 3 pipes they are different from those in class 1 pipes. In all cases, minor phreatomagmatism is likely during the waning phases of pipe eruption and the deposition of some pyroclastic kimberlites.

\section{REFERENCES}

Burnham, C.W., 1985. Energy release in subvolcanic environments: Implications for breccia formation. Economic Geology, 80, 1515-1522.

Cas, R.A.F., Wright, J.V., 1987). Volcanic successions, modern and ancient. Chapman and Hall, London.

Contact: E.M.W. Skinner, PO Box 2216, Grahamstown 6140, South Africa. E-mail: e.m.w.skinner@ru.ac.za
Clement, C.R., 1975. The emplacement of some diatreme-facies kimberlites. Phys. Chem. Earth 9, 51-59.

Clement, C.R., 1982. A comparative geological study of some major kimberlite pipes in the Northern Cape and Orange Free State, Ph.D. thesis (2 vols.) Univ. Cape Town.

Clement, C.R, Skinner, E.M.W., 1985. A texturalgenetic classification of kimberlites. Trans. Geol. Soc. S. Afr. 88, 403-409.

Clement, C.R., Reid, A.M., 1989. The origin of kimberlite pipes: An interpretation based on a synthesis of geological features displayed by southern African occurrences. Kimberlites and Related Rocks. Ross et al.1, 632-646.

Field, M., Scott Smith, B.H., 1999. Contrasting geology and near-surface emplacement of kimberlite pipes in southern Africa and Canada. Proc. 7 IKC. Eds. Gurney et al. 1, 214-237.

Hawthorne, J.B. 1975. Model of a kimberlite pipe. Phys. Chem. Earth 9, 1-15.

Lorentz, V., 2000. Formation of maar-diatreme volcanoes. Terra Nostra 2000/6:Int.Maar Conf., Daun/Vulkaneifel. 284-291.

Machin, K., 2000. Processes and products in kimberlitic crater facies of the South lobe, Jwaneng Mine, Botswana. MSc. Thesis, Rhodes Univ.

McCallum, M.E., 1985. Experimental evidence for fluidization processes in breccia pipe formation. Economic Geology, 80, 1523-1543.

Rice, A., 1999. Can the blasting excavation engineering sciences provide insight into the processes of kimberlite emplacement and eruption? Proc. 7 IKC. Eds. Gurney et al. 2, 699-708.

Smith, C.B., Lorentz, V., 1989. Volcanology of the Ellendal lamproite pipes, Western Australia. Kimberlites and Related Rocks. Ross et al.1, 505-519.

Wohletz, K.H., Zimanowski, B., 2000. Physics of phreatomagmatism. Terra Nostra 2000/6 :Int. Maar Conf., Daun Vulkaneifel. 515-523.

Wyllie, P.J. , 1987. Transfer of subcratonic carbon into kimberlites and rare earth carbonatites. In Magmatic processes :Physiochem. principles. Ed. Mysen, BO. The geochemical Soc. Special Publ. No. 1, 107-119. 